\title{
SUBJEKTIVE VIDNER FOTOGRAFIER SOM DOKUMENTATION AF HISTORIEN
}

\section{SUBJECTIVE WITNESSES: PHOTOGRAPHS AS DOCUMENTATION OF HIS- \\ TORY I Methodological approaches to photographic source material have been lacking in} historical research for a long time. In order to use photographs as historical source material, we need to take into account the specific abilities and limitations of the medium. In traditional methodological historical literature, photographs are treated uncritically and often serve merely as illustrations. In a few exceptions, they are treated as works of art, with references to the analytical methods from reception based picture analysis from art history, with the interpreting subject as focal point. New research that deals with photographs needs to deal with the source material more critically and use the meta sources available to verify and document the material. Also, it needs to take into account the specific contexts of the photographs as well as the general history and development of photography - culturally and technically - to add extra layers of information to the photographic documents. It is of particular importance in our mass producing, digital photo culture, as otherwise, traditional historians stand methodologically crippled before a lot of source material.

KEYWORDS | Photography, history, documentation, analysis, evidence, art, source material, research methodology

Billeder er stumme vidner og det er svart at oversatte deres vidnesbyrd til ord (Burke I4)I.

Peter Burke

Historiefaget er traditionelt et fag, der har sit fundament i arbejdet med de skriftlige kilder. Kilderne skal dateres, konteksten skal kendes, forfatteren skal gennemskues, budskabet skal gennemlyses, og hele valideringsprocessen leder slutteligt hen til en afgørelse af hvilke troværdige oplysninger, kilderne kan give forskeren til det videre analytiske arbejde. Arbejdet med kilderne er ofte en teksttung aktivitet, som består

I Peter Burke: "Images are mute witnesses and it is difficult to translate their testimony into words", (oversættelse, red.). 
af granskning og atter granskning af tekster. Men hvordan anskues fotografier som historiske kilder? Inden for kunsthistorie har faget længe forholdt sig til anvendelsen af fotografisk specifikke analysestrategier. Siden Erwin Panofskys Meaning in the Visual Arts har feltet udviklet en kulturteoretisk retning for fotografier som visuelt medie, og der har inden for de sidste årtier været en tendens i retning væk fra den kronologiske teknologihistorie mod en mere postmoderne anskuelse. Inden for kunstteorien og mediefilosofien findes således en anselig mængde værker, der forholder sig til fotografiet. Alligevel arbejdes der stadig inden for historiefaget med en flad forståelse af fotografiets anvendelse som kildemateriale, som efterlader historikere metodisk famlende i forhold til de masser af kildemateriale, der i dag produceres, ikke mindst digitalt. Der savnes med andre ord i dagens forskning og formidling et redskab til historikere, som gerne vil arbejde med fotografisk kildemateriale. Bør det analyseres som historikerens skriftlige kilde? Som kunsthistorikerens værk? Eller som etnologens kulturhistoriske genstand? Det er meget lidt, der i den kildekritiske faglitteratur er taget stilling til fotografiet som i sig selv meningsbærende kilde. I historieskrivningen bliver fotografiet oftest brugt ukritisk som appetitvækkende illustration til analysen af de skriftlige kilder. I det følgende behandles nogle overvejelser omkring forskellige tilgange til fotografier som kilder. Den historiske metodologi sættes i kontrast til den kunsthistoriske, hvor der i nyere tid søges et brud med en lineær tænkning af fotografihistorien en 'postfotografisk' genskrivning. Inden for historiefaget er der netop behov for den lineære, kronologiske tænkning, hvis materialet skal kunne afspejles i den historiske kontekst, det skal bidrage til at afdække.

\section{Imellem fotografiets linjer}

Fotografier viser i store træk, hvad der har været foran et kamera på et givent tidspunkt. Hvordan vi tolker fotografierne efterfølgende, beror på mange forskellige faktorer. Peter Burke skriver i Eyewitnessing. The Uses of Images as Historical evidence:

"Billeder er stumme vidner og det er svært at oversætte deres vidnesbyrd til ord. De er muligvis skabt med henblik på at kommunikere deres eget budskab, men historikere ignorerer ikke sjældent dette faktum for at 'læse imellem linjerne' i billederne og lære noget, som kunstnerne ikke var klar over, at de lærte fra sig.” (Burke I4)²

Hvordan kan man læse noget imellem linjerne i et billede? Det kan man enten ved at forestille sig subliminale beskeder, som længe har været tradition inden for kunsthistorien, eller ved at se forbi eller igennem fotografens umiddelbare forehavende og få øje på umærkbare detaljer. Historikere - lader Burke til at sige

"Images are mute witnesses and it is difficult to translate their testimony into words. They may have been intended to communicate a message of their own, but historians not infrequently ignore it in order to read pictures 'between the lines', and learn something that the artists did not know they were teaching." (Burke I4). 
- ser, hvad de vil se. De ignorerer afsenderens hovedbudskab, og finder små skjulte svar i billedet, som de efterfølgende formulerer spørgsmål til. Selvom Burke ikke udelt tilslutter sig læsning imellem linjerne, kan denne metode være frugtbar, hvis den benyttes med omhu. Fotografiets stamfader, Louis-Jacques-Mandé Daguerre, lavede sit første prospekt over Paris i I839. Prospektet, Boulevard du Temple, blev til alene fordi Daguerre ville demonstrere, at han kunne fastfryse et nøjagtigt billede af verden. Samtidig viser prospektet en I8oo-tals metropol, vi ikke ville kunne læse os til en fornemmelse af. Det bærer et videnslag, der ikke var tilsigtet, men er informativt for nutids-beskueren. Alle de visitkort og kabinetkort, der blev produceret i I8oo-tallet for at give modtagerne informationer om de afbildedes status, smag og interesser, er ligeledes ladet med informationer om klædedragthistorie, materiel kultur, kønsroller etc. Billeder siger ikke kun det, fotograferne havde tænkt sig; vi finder nye ting i dem, som af forskellige årsager har interesse for os i dag. Billeder har forskellige kontekster, men også forskellige meningslag afhængigt af beskueren og dennes kontekster.

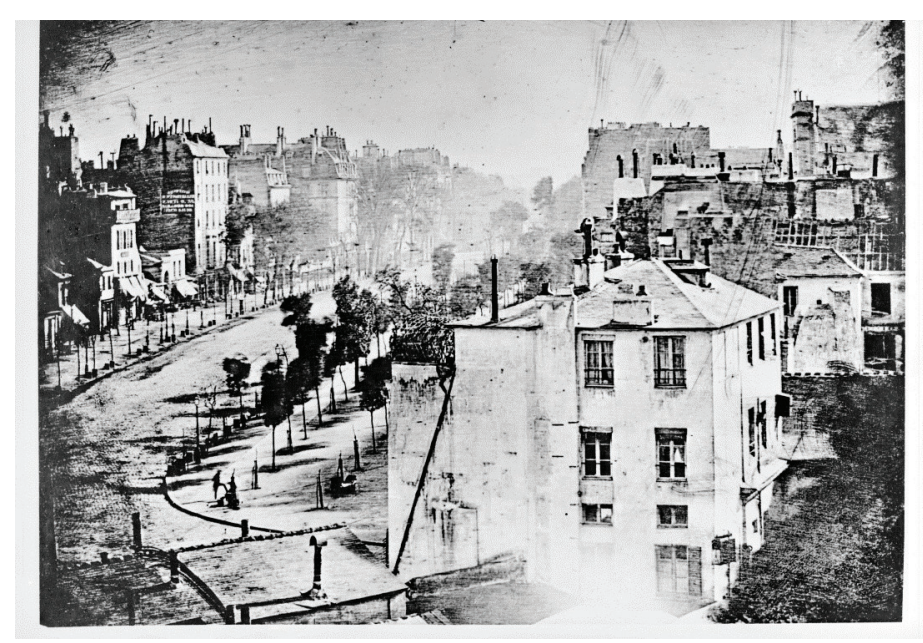

\footnotetext{
Verdens første fotografi af et menneske - en mand, der får pudset sko. Daguerreotypi af Louis-Jacques-Mandé Daguerre - Boulevard du Temple, Paris, 1839. () Bayerisches Nationalmuseum München.

Foto: Marianne Stöckmann.
}

Selve indholdet i fotografiet kan også snyde. Fotografier har altid kunnet manipuleres og manipulere. Også når det ikke har været fotografens hensigt at snyde beskueren, kan de fortælle halve sandheder. Daguerres Paris-prospekt - eller 'byskab' - viser et tomt Paris uden det menneskemylder, vi ville kunne forvente i Frankrigs hovedstad på det tidspunkt. Det vækker forundring, indtil vi lærer, at 
eksponeringstiden på dette tidlige daguerreotypi var adskillige minutter.3 De mennesker, der sikkert passerede foran linsen i hobetal i det tidsrum, er ikke kommet med. De bevægede sig simpelt hen for hurtigt. Kun en enkelt figur har holdt sig stille nok til at komme med: En mand, der får pudset sko. For at gennemskue dette tekniske synsbedrag må vi kende til fotografiets historie. Ligeledes med de prangende rekvisitter, der udgør scenografien i visitkort (fra ca. I860) og kabinetkort (fra ca. I866) frem til de første årtier af I90o-tallet. Hvis vi ikke vidste, at det var fotografens egne rekvisitter, som blev brugt igen og igen, og at folk klædte sig i deres allerbedste tøj, når de skulle have taget deres kontrafej, kunne vi let forledes til at tænke, at det enten kun var de rigeste, der havde råd til at lade sig fotografere, eller at nogen havde gjort et dårligt forsøg på at snyde beskueren til at tro, at de fotograferede rent faktisk stod midt i en græsk søjlegang i stedet for foran et malet bagtæppe i et atelier. For at kunne bruge detaljerne rigtigt og vide, hvad det egentlig er, fotografierne kan fortælle, er det nødvendigt at kende konteksten. Fotografihistorien - historien om mediets teknologiske udvikling - hjælper os til at vurdere, hvad vi kan læse mellem linjerne i et givent fotografi. Den hjælper os, i tråd med grundprincipperne i den historiske metode, til at øve en for historiefaget væsentlig kildekritik.

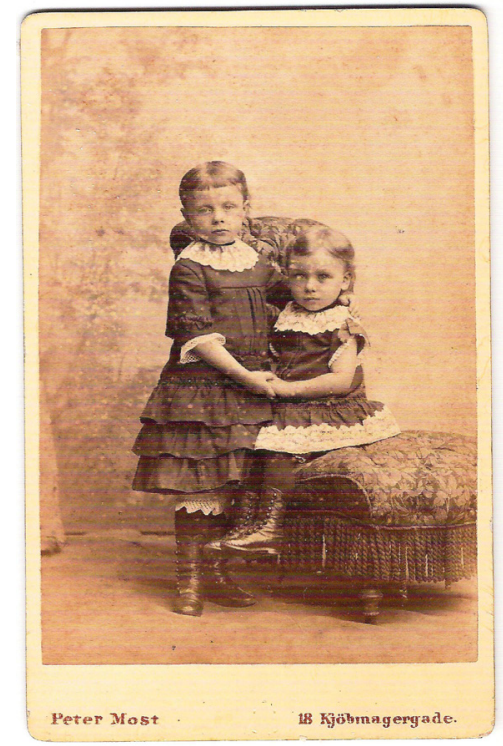

\footnotetext{
Foreviget i det pæne tøj. Visitkort fra slutningen af 1800 -tallet. Fotograf Peter Most, København. Privateje.
} 


\section{Kontekstualisering - ikke kunstificering}

Daguerres Paris-prospekt og de masseproducerede visit- og kabinetkort er eksempler på billeder, der er fyldt med mening - vel at mærke ikke nødvendigvis for os i dag den mening, der blev tillagt dem ved produktionen. For kunsthistorikere sker den billedanalytiske afkodning automatisk, men det traditionelle historiefag er billedmæssigt traditionsløst og metodisk underudviklet til trods for, at også historikere ved at læse imellem linjerne kan få adgang til store uudnyttede ressourcer af historisk empiri. Vi kan kun stå på skuldrene af kunsthistorien med det ene ben; det andet må finde sin egen base i historievidenskabens metodik. Mange elementer kan vi adoptere fra den klassiske kunsthistoriske billedanalyse, men der er også mange, der er direkte uforenelige med historisk metode og analysestrategi. Desværre får vi ikke i den eksisterende historiefaglige metodelitteratur særlig mange hints til hvilke sten, vi kan bruge til at bygge basen til det fritsvævende ben af.

I Sebastian Olden-Jørgensens Til kilderne! Introduktion til historisk kildekritik giver han som årsag for sin udeladelse af en gennemgang af ikke-skriftlige kilder, at "de fleste kildekritiske pointer også gælder for ikke-skriftlige kilder, samt at de særlige metodiske principper for billedanalyse, udgravninger, surveys etc. på linie med mange andre specifikke metoder falder uden for sigtet med denne bog”. (Olden-Jørgensen I2) Jo vist, den naturlige kritiske læsning af en tekst svarer til den naturlige kritiske anskuelse af et billede; men de særlige metodiske principper, der tillige bør anvendes i forbindelse med afkodningen af et billede, bør udvælges med lige så stor omtanke og kritisk sans som selve kildematerialet. Hvad angår metode til billedanalyse, vil det hyppigt være kunsthistorien, der trækkes på.

Knut Kjeldstadli anbefaler direkte i Fortiden er ikke hvad den har varet - en indføring $i$ historiefaget, at historikeren kigger kunsthistorikeren over skulderen. I den kunsthistoriske tilgang til billedværker kan disse, ifølge Kjeldstadlis udlægning, angribes fra fire forskellige vinkler: med fokus på det autonome værk som form; med fokus på kunstneren/udtrykket; med fokus på virkelighed/imitation-forholdet; og med fokus på iagttageren/oplevelsen. Han foreslår, at man analyserer billedværker i følgende orden:

I. Ophavsbeskrivelse

2. Teknisk analyse

3. Formal beskrivelse

4. Motivanalyse (emneanalyse)

5. Fremstilling af, hvad billedet 'udsiger', af den 'dybere mening'. (Kjeldstadli 208)

Ophavsbeskrivelse inkluderer ophavsmand, datering og sted. Den tekniske analyse beskriver bl.a. fremstillingsmåde, materiale og størrelse, og kan i nogle tilfælde bruges til datering. Ved fotografier kan den tekniske analyse afsløre, om der er manipuleret med billedet, hvilket er et essentielt spørgsmål i kildekritisk sammenhæng. Den formale beskrivelse retter sig mod analyse af rummet og perspektivet. 
Motivanalysen er den del af billedgranskningen, hvor selve de meningsbærende elementer i billedet kommer under luppen. Her kommer selve det narrative frem, konstitueret af de enkelte objekter eller delelementer i billedet, der samlet danner det overordnede indtryk, og placeret i den stilmæssige kontekst for produktionsperioden. Det sidste punkt - hvad Kjeldstadli kalder "meningen med billedet" (2I2) - beror for en stor del på beskuerens evne til at læse symbolikken, allegorierne i billedet; at finde "mønstre i den billedmæssige retorik" (2I3). Det er her, vi fortolker ud fra en forståelse af motivets konkrete formsprog og dets umiddelbare formål i forhold til beskueren. Det har ikke været Kjeldstadlis formål at give en grundig redegørelse for de mange problempunkter, der er forbundet med brugen af billeder som kilder, på de få sider, han har afsat til det. Den kritiske tilgang må vi finde andetsteds.

Kjeldstadlis tilgang til billedmaterialet er baseret på bl.a. Erwin Panofskys Meaning in the Visual Arts fra 1955, som er et kunsthistorisk værk. Der har længe inden for kunsthistoriens receptionsorienterede billedanalyse været tradition for, at beskueren læste sit eget subjekt ind i kunstværket; at modtageren så at sige tolkede afsenderens budskab ud fra sin egen bevidsthedssfære. Kunsthistorikerens receptionsorienterede tilgang til billedverdenen er ikke brugbar i historieskrivningen; især ikke når fotografiet skal agere vindue til verden som den var, og ikke som den måske blev følt af fotografen. Det er let at forfalde til overfortolkning, hvis man analyserer fotografier som malerier. Fotografier kan være fulde af symbolik, men de er det ikke per definition. Flyver en due forbi linsen i samme øjeblik, som der trykkes på udløseren, kommer den med på billedet, uden at fotografen nødvendigvis har tænkt store tanker om fred eller Helligånden. Og selvom lyset i Kristendommen er et symbol på Jomfru Maria, er det ikke årsagen til, at præ-fin-de-siecle-fotografer ofte har valgt at fotografere udendørs i direkte sollys. Det er snarere et spørgsmål om, hvad der var teknisk muligt i tiden før kunstig belysning og blitz. Når fotografier bruges som historisk kildemateriale, må den kunsthistoriske receptionsmetode vige for en anderledes granskning af det konkrete materiale. Her kræves en mere kildekritisk billedanalyse, som kender sin fortolkningsmæssige begrænsning.

I Povl Ellers Historisk Ikonografi fra 1964 får vi en tidlig vurdering af billedmaterialets værdi som historisk kilde. På udgivelsestidspunktet var det kun godt 30 år siden, man var begyndt at forholde sig til billeder inden for historieskrivningen, men bogen er anvendelig selv i dag, hvor man kan savne en lige så engageret interesse for selve det at finde og bruge billedmateriale. Eller skelner som udgangspunkt imellem ikonografi, ikonologi og historisk ikonografi. Ikonografien, som kan være kirkelig eller verdslig, har inden for kunstvidenskaben siden det I9. århundrede været defineret som "forskning, der behandler billedkunsten ud fra emnets eller motivets synspunkt” (Eller 9). Den er bredt forstået en "beskrivende videnskab, der søger sammenhæng fra billede til billede” (9-IO). Ikonologien, derimod, definerer en søgen "gennem litteraturhistorie, lærdomshistorie og idéhistorie" efter at "knytte kunstens historie til den almindelige historievidenskab" (9-IO). 
Betegnelsen 'historisk ikonografi', som er fokusset for bogen, blev ifølge Eller fasttømret med den internationale komité for historievidenskabs i I928 nedsatte kommission for ikonografi. "På baggrund af den hyppige tale om billedernes historiske kildeværdi kan man sige, at denne gren af ikonografien beskæftiger sig med billedernes forhold til den virkelighed, de foregiver at fremstille" - herunder især portrætter. (IO) Historisk ikonografi er således i denne terminologi den del af ikonografien, der behandler billeder som historisk vægtige udsagn, der skal og kan behandles kritisk på lige fod med andre typer historiske kilder. Det skal her bemærkes, at Lars Kiel Bertelsen så sent som i 2000 i Fotografiets grå mytologi pointerer, at fotografihistorien stadig savner en ikonografi, og han henviser til, at "[t]raditionelle kunsthistoriske metoder som ikonografien og formanalysen kan [...] hjælpe os til bedre at se fotografiske billeder" (Bertelsen I6). Samtidig advarer han mod, at ikonografien bliver "naturaliseret" og gjort "myte", men derimod bliver fleksibel - en mere “åben’ eller 'blød' ikonografi, en ikonografi modereret af aktualiseringens perspektiv”. (I6-I7) Bertelsens modererede ikonografi, som er hans analytiske udgangspunkt for Fotografiets grå mytologi, er i princippet også den rette vej til at tage fotografiet ud af kunsthistoriens monopoliserede greb og introducere det til et nyt fagområde med en aldeles anderledes metodisk og analytisk tradition. Derfor er det væsentligt med en grundlæggende forståelse for ikonografiens principper. Den gode nyhed er, at de ikke adskiller sig dramatisk fra historikerens klassiske kildekritiske læsning af tekster, hvor man starter med at få de ydre rammer for tilblivelsen på plads før man begynder at analysere ud fra værk og kontekst.

Ligesom Kjeldstadli skitserer Eller punktvist fremgangsmåden for en historisk billedanalyse, dog med større hensyntagen til den sædvanlige kildekritiks nødvendigheder. Eller lægger sine væsentligste hovedpunkter omkring billedbehandlingen ind under kapiteloverskrifterne "Billedundersøgelsen" og "Kritikken af billedet". De deles ind i følgende underafsnit:

Billedundersøgelsen:

I. Benævnelsen

2. Teknik og materiale

3. Mål og form

4. Påskrifter

5. Rammen

6. Proveniensen

7. Bevaringstilstanden

8. Beskrivelsen

9. Portrætbeskrivelsen

Io. Beskrivelsens form

De fleste punkter giver sig selv, dog kan punkt 8, 9 og Io klare en differentiering. Med beskrivelse menes den korte, nøgterne beskrivelse, der findes i et museums 
eller arkivs registrant. Med portrætbeskrivelse menes portrættets udsnit (eksempelvis 'halv figur' eller 'skulderstykke'), vinklen på den portrætterede (eksempelvis 'en face' eller 'halv profil') samt den portrætteredes individuelle karakteristika (øjen- og hårfarve, beklædning, smykker, våben og lignende udstyr, samt hånd- og benstilling). Med beskrivelsesform menes helt konkret registreringskortet hvorpå beskrivelsen er noteret. Selv med digitaliseringen af registranterne - og måske endda især på grund af den - kan det sidste punkt have stor relevans, afhængigt af hvad man ønsker at bruge materialet til. Hvor de er kendt og eksisterende, må Ellers punkter under billedundersøgelsen medtages i den indledende undersøgelse af det fotografiske kildemateriale. Selvom Ellers umiddelbare mål har været at lette registreringsarbejdet for arkiv- og museumsansatte, giver oversigten et godt overblik over, hvad der kan sammenfatte det udvalgte billedmateriales karakteristika, og den lægger en god bund for den videre analyse. Det er dog især den anden del af billedanalysen, "Kritikken af billedet", der er interessant i denne sammenhæng. Det er nemlig ofte den, der volder flest problemer når det drejer sig om fotografier.

Kritikken af billedet:

I. Identifikationen

2. Dateringen

3. Ophavsmanden

4. Billedets historie

5. Gengivelser af billedet

Identifikationen er forholdsvis uproblematisk, hvis for eksempel ophavsmanden har skrevet portrætteredes navn på selve billedet. Er det ikke tilfældet, kan det være noget nær umuligt at finde frem til den portrætteredes navn, med mindre der findes andre kilder til identificering. Selv hvis navnet står på billedet, er det nødvendigt at medregne, at indskriften kan være er påført senere. Det er her nødvendigt at kende billedets proveniens. Det samme gælder dateringen. Hvad angår tilskrivningen af et værk - fastslåelse af ophavsmanden - kan det ligeledes være noget nær umuligt at opspore. Hvor det er muligt, må det naturligvis tilstræbes, da det tilføjer betydning at kende ophavsmandens motivation og kontekst. Med billedets historie kommer der lidt mere kød på værket. Her undersøges omstændighederne for billedets tilblivelse og brugen af det i eftertiden. Med gengivelser af billedet forstås reproduktioner af forskellig art, som også kan bidrage til at afsløre noget omkring billedets status, brug og udbredelse. De forskellige punkter under "Kritikken af billedet" kan gennemgås slavisk i forhold til et enkelt værk, eller repræsentere hver deres studieretning, afhængigt af hvad man ønsker at undersøge. Kender man portrætterede, kan man sætte billedet ind i vedkommendes biografiske historie; kender man årstallet, kan man relatere billedet til dets historiske samtid; kender man kunstneren, kan man drage paralleller til hans øvrige værker; kender man billedets historie, kan man skrive mentalitetshistorie; og kender man til gengivelser af billedet, kan man anskue dem i relation til udviklingen inden for forskellige reproduktionsteknikker. 
Hvor Knut Kjeldstadli forholder sig nogenlunde ukritisk til den kunsthistoriske tilgang til billeder, er Povl Ellers tilgang til den historiske ikonografi noget mere anvendelig inden for historiefaget. Begge tilgange er dog hovedsageligt funderet $i$ analyse af malerier, og med fotografier er det nødvendigt at anvende lidt anderledes tilgange til kilderne. De er ikke kunstværker - eller i hvert fald: De er ikke nødvendigvis kunstværker.

\section{Det scerligt fotografiske}

Vi kan ofte genkende klassiske kompositoriske og æstetiske principper i fotografier, og især fra fotografiets første århundrede finder vi motiver, der klart refererer til malerkunstens pittoreske virkelighedsgengivelse i samtiden. Men det er et andet medie. Som Susan Sontag skriver i den nu klassiske On Photography fra I97I: "I den almindelige retorik omkring det fotografiske portræt er det, at sidde foran kameraet, udtryk for højtidelighed, åbenhed, åbenbarelse af subjektets essens”. Og, fortsætter hun,

"På trods af alle de måder, hvorpå malere og fotografer siden I840'erne gensidigt har påvirket og plyndret fra hinanden, er deres metoder fundamentalt modstillede. Maleren konstruerer, fotografen åbenbarer. Det vil sige, identifikationen af et subjekt $i$ et fotografi dominerer altid vores betragtning af det - hvilket det ikke nødvendigvis gør i et maleri” (Sontag 92).4

Fotografen registrerer, maleren opbygger. Fotografiet vækker nysgerrighed i forhold til motivet, maleriet vækker lige så hyppigt nysgerrighed i forhold til den tekniske udførsel. Hvis der forekommer at være 'åbenbarelse', i et maleri, er det en del af en opbygget narrativ. Og den gælder ikke, ifølge Sontag. Der er flere problempunkter i Sontags udlægning; den noget skarpe adskillelse af de to medier er ikke altid så skarp i virkeligheden, og hendes argumenter har i den typiske amerikanske essayform ikke tilstrækkelig empirisk understøttelse. Men grundlæggende og principielt set har hun ret: Om end de to visuelle medier minder uhyrligt meget om hinanden, er de fundamentalt set lige så forskellige som en statue og en gobelin, og må derfor også behandles som så. Der skal ikke her skeles meget til de tidligere fototeoretikeres udlægninger af fotografiets kompleksitet, om end eksempelvis Walter Benjamin med "Kleine Geschichte der Photographie" (I93I), Susan Sontag med On Photography (197I), Roland Barthes med La Chambre Claire (I980) og Vilem Flusser med Für eine Philosophie der Fotografie (1983) har markeret sig som kritikere, der stræber efter at definere fotografiets særlige egenskaber - dets 'essens'. Ofte

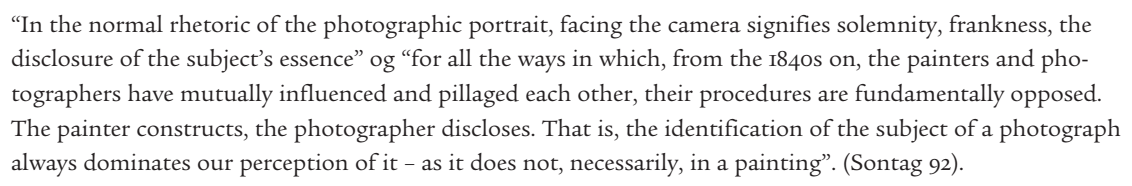

"In the normal rhetoric of the photographic portrait, facing the camera signifies solemnity, frankness, the disclosure of the subject's essence" og "for all the ways in which, from the I84OS on, the painters and photographers have mutually influenced and pillaged each other, their procedures are fundamentally opposed. The painter constructs, the photographer discloses. That is, the identification of the subject of a photograph always dominates our perception of it - as it does not, necessarily, in a painting". (Sontag 92). 
- og i hvert fald i disse tilfælde - er der i højere grad tale om filosofiske betragtninger over fotografiet som et stykke af verden, der ikke helt lader sig definere, end teori. I sommeren 2006 holdt Nordic Network for the History and Aesthetics of Photography konference i Sverige om 'photographic specificiality' - det særligt fotografiske ved fotografiet - hvor det slutteligt kunne fastslås, at en sådan 'specifikalitet' om ikke andet var svær at beskrive. Men det udelukker ikke muligheden for, endsige nødvendigheden af, at beskrive fotografiet som fotografi - og ikke bare som et billede. Som antropologen Jay Ruby formulerer det:

“...studiet af billeder alene, som objekter hvis mening er iboende, er en fejlagtig metode, hvis man interesserer sig for de måder, hvorpå mennesker tillægger billederne mening. Vilkårene for produktion og brug må forstås før billedets mulige betydninger kan undersøges. [...] Selvom nogle fotografier er skabt til at blive regnet for kunst, er de fleste ikke, og derfor lider de under at blive betragtet som så. Ifølge kunsthistorikere er langt de fleste fotografier ikke er værd at kigge på, og da slet ikke at studere. Socialhistorikere foreslår, at ethvert fotografi, der kan knyttes kontekstuelle informationer til, kan afsløre interessante ting om de mennesker, der fremstillede og brugte det. [...] Som socialt konstruerede kulturgenstande anskues fotografier som objekter af en materiel kultur, der afslører noget omkring den kultur, der er afbildet, såvel som billedskaberens kultur. Med denne tilgang er det logisk, at dette studie [Secure the Shadow, 1995] har anvendt de metodiske tilgange fra antropologien, socialhistorien og etnografien frem for mainstream kunsthistorie." (Ruby 5-6)5

Denne tilgang bør også være fundamentet for brugen af fotografier i historievidenskaben. Konteksten er altafgørende. Som Eller skriver:

"Hele vor opfattelse af den betydning, man i samtiden har tillagt billedet, er afhængig af de forestillinger, vi gør os om dets historie. Hvorfor er det blevet til, hvem har taget initiativet, under hvilke omstændigheder blev det skabt? Hvad ønskede den afbildede, og hvilke tanker gjorde han sig om det, hvad mente hans pårørende, og hvad mente offentligheden? Hvad mente kunstneren, og hvad tog han for det?" (Eller 6)

"...the study of images alone, as objects whose meaning is intrinsic to them, is a mistaken method if you are interested in the ways in which people assign meaning to the pictures. The conditions of production and consumption must be understood before the image's possible meanings can be examined. [...] While some photographs are designed to be regarded as art, most are not and therefore suffer when so scrutinized. Art historians argue that the vast majority of photographs are not worth seeing, let alone studying. Social historians suggest that any photograph, provided there is some contextual information accompanying it, can reveal something interesting about the people who made and used it.[...] As socially constructed artifacts, photographs are regarded as objects of material culture that reveal something about the culture depicted as well as the culture of the picture taker. Given this approach it is logical that this study [Secure the Shadow, 1995] employed the methods of anthropology, social history, and ethnography rather than mainstream art history." (Ruby 5-6). 
Disse spørgsmål er essentielle i diskussionen om fotografiets potentiale som primært historisk kildemateriale. Til at danne metodisk ramme om den grundlæggende analyse af fotografisk kildemateriale er Ellers underpunkter fra "Kritikken af billedet" velegnede. Overvejelser omkring identifikation af den portrætterede, datering af billedet, ophavsmand, billedets historie, gengivelser og dertil autenticitet (er billedet manipuleret?) bør indgå som verifikation og dokumentation af et fotografi, når det skal bruges som kildemateriale. Fotografiet kan kun være meningsbærende kilde ved en forudgående kontekstualisering og en forståelse af dets historie og særegenskaber som fotografisk medie. For historikere vil forståelsen af det særligt fotografiske dog være nært forbundet med forståelsen af selve mediets udvikling - både den teknologiske udvikling og udviklingen af dets betydning i samfundet. Fotofilosofiske redegørelser for fotografiets 'aura' hjælper ikke til forståelse af fotografiets specificitet. I historievidenskaben er den æteriske kilde uaktuel.

\section{Metakildernes betydning for forståelsen af fotografierne}

Det fotografiske kildemateriale bør således altid placeres i dets historiske kontekst. Et studie med fotografier som primære kilder er nødvendigvis en øvelse i at afkode, hvad fotografiet tilføjer sin samtid, og hvad samtiden tilføjer fotografiet. Som Burke skriver: "Billeders udsagn rejser, ligesom teksters udsagn, problemer i forhold til kontekst, funktion, retorik, genkaldelse (kort eller lang tid efter begivenheden), andenhåndsbevidnelse og så videre" (Burke I5). ${ }^{6}$ Desværre, fortsætter han, er det at placere dem i en kontekst ikke altid så nemt,

"eftersom de afbildedes og fotografernes identiteter meget ofte er ukendte, og fotografierne selv, som oprindeligt - i mange tilfælde - var en del af en serie, er blevet adskilt fra det projekt eller album, de oprindeligt blev fremvist i, og er endt på arkiver eller museer”. 7

De kulturhistoriske spørgsmål, som Eller stiller i sin analyseplan - hvad syntes samtiden om billedet, hvorfor er det blevet til, på hvis initiativ, under hvilke omstændigheder, hvordan forholdt den portrætterede, hans pårørende, offentligheden og kunstneren sig til det - er nødvendige at stille til alle fotografier, hvis de ikke bare skal bruges som illustrationer. Kender vi til omstændighederne for fotograferingen og de impliceredes individuelle ønsker, kan vi bedre bedømme i hvilket omfang motivet er arrangeret for kameraets skyld, og i hvilket omfang det er registreret uden anden menneskelig interferens end fotografens tryk på udløserknappen. Spørgsmålet om, hvorvidt det afspejler virkeligheden, er til stadig debat; det er

6 "[T]he testimony of images, like that of texts, raises problems of context, function, rhetoric, recollection (whether soon or long after the event), secondhand witnessing and so on". (Burke I5).

7 "[S]ince the identity of the sitters and the photographers is so often unknown, and the photographs themselves, originally - in many cases, at least - part of a series, have become detached from the project or the album in which they were originally displayed, to end up in archives or museums". (Burke 22). 
mere interessant at kigge på bvilken virkelighed, det afspejler. Er det samtidens æstetiske krav? Er det den portrætteredes verdenssyn? Er det fotografens? Eller er det en senere manipulatørs? Hvis fotografiet f.eks. er efterkoloreret, har vi hele to ophavsmænd, og resultatet må afspejle begges æstetiske præferencer. Ved portrætter har den portrætterede også haft noget at sige i processen inden det færdige resultat. Vi kan i langt de fleste tilfælde gå ud fra, at resultatet er et produkt af både fotografen, den portrætterede og indirekte den 'usynlige' beskuer, via de i processen impliceredes forventninger til de senere beskuere.

Det er også nødvendigt at anerkende betydningen af malerkunstens indvirkning på fotografiet, når fotografiet tydeligt mimer de klassiske kompositionelle træk. Alene de traditionelle portrætpositurer er overtaget fra malerkunsten. Det kan også være de lidt mere sublime adoptioner, som da Henry Peach Robinson i fotografiets barndom trak på bl.a. præ-Raphaeliternes romantiske fremstillinger af døende kvinder med Fading Away (I858). Men det går også den anden vej, hvor fotografier bliver brugt som forlæg til andre kunstarter. I popkunstneren Andy Warhols farverige Marilyn Monroe-silketryk godt hundrede år senere (I962) er der tale om en direkte manipulation af den forstørrede udgave af det oprindelige fotografi - en poppet 'efterkolorering'. Adoptionerne har dog gerne mere sublimal karakter, som når det socialrealistiske fotografi låner symbolik og komposition fra genremaleriet, og omvendt, når den realistiske malerkunst låner fra samtidens fotografi. Fotografering som indledende studie var et uundværligt arbejdsredskab som forlæg eller skitse for bl.a. skagensmalerne; (jf. Fabritius 7; Saabye) alligevel står det i kunsthistorien som en lidt pinlig fodnote, som om det betragtes som snyd, at man har kigget efter noget, der kunne ligge i en skuffe.

For at kunne lave en beskrivelse af billedets historie, herunder dets historiske samtid og dets placering i den, er det nyttigt at kunne inddrage andre kilder end fotografierne selv, om end det i de færreste tilfælde vil være muligt rent faktisk at finde ud af fotografens, den portrætteredes og de pårørendes tanker og ønsker i forbindelse med fotograferingen. Et sjældent eksempel er H.C. Andersen, som skrev i sin dagbog lørdag den 26. september I874: "Solskin. Gik klokken elleve til Hoffotograf Hansen og blev der, tandløs, som jeg er fotograferet i Cabinets og i enkelt Kort-format” (Andersen 329). Her får vi datoen for fotograferingen, en beskrivelse af portrætterede, fotografiernes formater samt fotografens navn, 'Hoffotograf Hansen', det vil sige Georg E. Hansen. Vi får sågar en vejrmelding. ${ }^{8}$ Findes sådanne beskrivende metakilder fra samtiden - f.eks. fotografprotokoller, dagbøger, breve eller lignende førstehåndskilder - er det muligt at tale specifikt om fotografiernes kontekst ud fra modtagerens, ofte den portrætteredes, eget udsagn. Men det er også muligt at gøre generelle iagttagelser af kulturhistorisk værdi uden skriftlige metakilder. Har vi f.eks. flere af den samme type billeder, kan vi måske tale om en tradition. Et eksempel er traditionen for at tage atelierportrætter af de uniformerede

8 På Det Kongelige Biblioteks hjemmeside er anført at "H.C. Andersen [blev] fotograferet af Georg E. Hansen d. 26. september 1874 “. "Portrætter af HCA". Link til s. 329 i dagbogen. 
I864-soldater inden de gik i krig. Vi kan ofte finde mange informationer om den bredere sociale og kulturelle kontekst for fotografierne, for eksempel hele opløbet til nationalstatstanken og soldaternes rolle i den, selvom de individuelle billeder er 'anonyme'. Skriftlige førstehåndskilder omkring tidens politiske miljø kan give et indblik i mentaliteten i tiden. Andenhåndskilder vil typisk være de mest tilgængelige; også de kan være medvirkende til at give billederne dybde ved en kontekstualisering. Fotografiets muligheder er begrænsede, hvor der ikke findes samtidige skriftlige kilder, der omtaler det; men øvelsen kan være frugtbar med kendskab til mediets historik samt dets særlige begrænsninger og muligheder.

Der er gjort gentagne forsøg på at vise, at fotografier ikke er sandhedsvidner, og at de manipuleres og manipulerer. Men netop på grund af det autenticitetsry, som fotografier i modsætning til malerier ofte har, og som det næsten er umuligt at bryde igennem, er det nødvendigt med en vurdering af deres brug som primærkilder. Det er velkendt, at fotografier meget nemt kan manipuleres; ikke mindst i dag, hvor man med det rette billedbehandlingsprogram kan udviske alle grænser imellem fantasi og virkelighed. Alligevel har de stadig et potentiale til at bidrage til kulturhistorien med informationer om deres samtid. Meget ofte viser de bare det, de er et billede af. I de fleste kulturer vil et fotografi af et træ blive genkendt, fordi fotografiet om noget medie kan gengive verden, som den faktisk ser ud, objektivt. Selvom den pågældende kultur ikke nødvendigvis vil genkende fotografiet som fotografi, vil den i hvert fald genkende træet som træ.

\section{Den digitale supervirkelighed}

Motivationerne bag brugen af det fotografiske medie og tilgangen til det for producenter og beskuere har ændret sig i løbet af det sidste godt halvanden århundrede, fra Daguerre fremviste sine forste 'sandhedsvidner', til i dag hvor digitaliseringen byder os bearbejdede billeder hvor end vi kigger hen. Den betagelse ved selve det at kunne fotografere, som syntes uløseligt klæbet til fænomenet i starten, er for længst forsvundet. Sjældent vil vi stoppe op og filosofere over denne ufattelige lighed med Verden, der gengives i fotografiet. Den amerikanske poet Edgar Allan Poes beskrivelse af fænomenet i I840, kort efter processens frigivelse, giver et indtryk af overvældelsen ved alene det at kunne reproducere nøjagtigt, 'sandt', efter naturen:

"Måske, hvis vi forestiller os den skarphed, hvormed et objekt genspejles i et fuldkommen perfekt spejl, kommer vi så tæt på virkeligheden, som det er muligt. For Daguerreotypi-pladen er i sandhed uendeligt (vi anvender betegnelsen med velberåd hu) uendeligt mere præcis i sin repræsentation end noget maleri udført af menneskehænder. Hvis vi undersøger et almindeligt kunstmaleri i et kraftigt mikroskop, vil alle spor efter lighed med naturen forsvinde - men det grundigste studie af det fotogene afslører kun en mere absolut sandhed, en mere perfekt identitet af udseende med det, det repræsenterer. Variationerne i 
skygge og graderingerne af både lineære og æteriske perspektiver tilhører sandheden selv, med deres overlegne perfektion" (Poe 2).9

Selve det, at fotografiet rent principielt og essentielt gengiver virkeligheden bedre end eksempelvis et maleri, kan vi ikke længere imponeres over. Hvor fotografiet tidligere havde status af noget helt enestående, er det i dag noget helt almindeligt. Vi er nærmest nået dertil, hvor vi ikke engang betages over at fotografier ikke ligner virkeligheden længere. De supervirkelige, manipulerede billeder, der har oprindelige virkelighedsgengivelser som base, men er så stærkt digitalt ændrede, at de er holdt op med at ligne virkeligheden og nærmere ligner virkeligt veltegnede tegnefilmsfigurer, kan vi ikke engang imponeres over længere. Den digitalt ændrede karakter bag den filmiske fremstilling af Tolkien-figuren Smeagol, for eksempel, accepterer vi uden forbehold som en del af den moderne, superreale filmfiktion.

I dag er det digitale billedsprog både en professionel og en personlig kreativ proces - en slags æstetisk billedlig signatur, som vi afkoder pr. automatik, også når vi eksempelvis besøger Facebook, LinkedIn og andre sociale medier. Vores profilportræt er vores fingeraftryk, og det fortæller ikke kun hvordan vi ser ud, men også om vi er kunstnerisk anlagte (f.eks. manipulerede farver), klassisk højtidelige (sort/hvid) eller 'private' (f.eks. et billede af vores husdyr i stedet for os selv). Udviklingen fra det tidlige fotografi, som var en udstyrskrævende teknologi, til det digitale foto $\mathrm{i}$ dag, som med en mobiltelefon trylles direkte ud i cyberspace med ganske få fingerbevægelser, sætter yderligere krav til analysen af fotografiet. De gamle, 'fysiske' billeder har teknologihistorien lært os at datere ud fra fremstillingsprocessen og formatet, og som visuelle etnologer kan vi komme nærmere en datering og lokalisering ved at kigge på klædedragter og øvrigt udseende på de portrætterede. De gamle, 'fysiske' billeder indeholder af og til påskrifter, som bidrager med nyttig viden om det, billedet forestiller. Digitale billeder er kodet med andre oplysninger. De kan indeholde automatisk lagrede oplysninger om optagelsestidspunkt, ændringer, endda geografiske koordinater, hvis kameraet har GPS. Eller de kan indeholde ingenting. Ingen oplysninger overhovedet. Det digitale fotografi stiller sine egne krav til den metodologiske tilgang til fotografier som historisk kildemateriale.

De kreative udfoldelsesrammer i retning af billedmanipulation er demokratiseret på lige fod med selve mediet, og som også Lars Kiel Bertelsen er inde på i Fotografiets grå mytologi, er der behov for en blød ikonografi, som anerkender tidernes skiftende syn, hvis vi skal kunne følge med udviklingen. Man kunne tilføje, at der

9 "Perhaps, if we imagine the distinctness with which an object is reflected in a positively perfect mirror, we come as near the reality as by any other means. For, in truth, the Daguerreotyped plate is infinitely (we use the term advisedly) is infinitely more accurate in its representation than any painting by human hands. If we examine a work of ordinary art, by means of a powerful microscope, all traces of resemblance to nature will disappear - but the closest scrutiny of the photogenic discloses only a more absolute truth, a more perfect identity of aspect with the thing represented. The variations of shade, and the gradations of both linear and aerial perspective are those of truth itself in the supremeness of its perfection". (Poe 2). 
inden for historiefaget er behov for en blød historisk ikonografi, som også forholder sig kronologisk til billedmediet. Bertelsen foreslår netop det modsatte som vejen frem inden for de visuelle studier. Med det digitale fotografi opholder vi os ifølge Bertelsen i "den postfotografiske æra”:

"[H]vis det digitale fotografi virkelig har afsluttet eller defineret den fotografiske epoke, så mangler der i ekstrem grad en postfotografisk gennemskrivning af fotohistorien, der kan modsvare de postmodernistiske positioner, der er fremskrevet inden for snart sagt alle andre æstetiske områder. Dette nye blik, som jeg ikke vil kalde digitalt, men gerne postfotografisk, gør det muligt at genlæse fotografihistorien ud fra andre optikker end de, der hidtil er blevet bragt i anvendelse i forhold til fotografier" (Bertelsen I8).

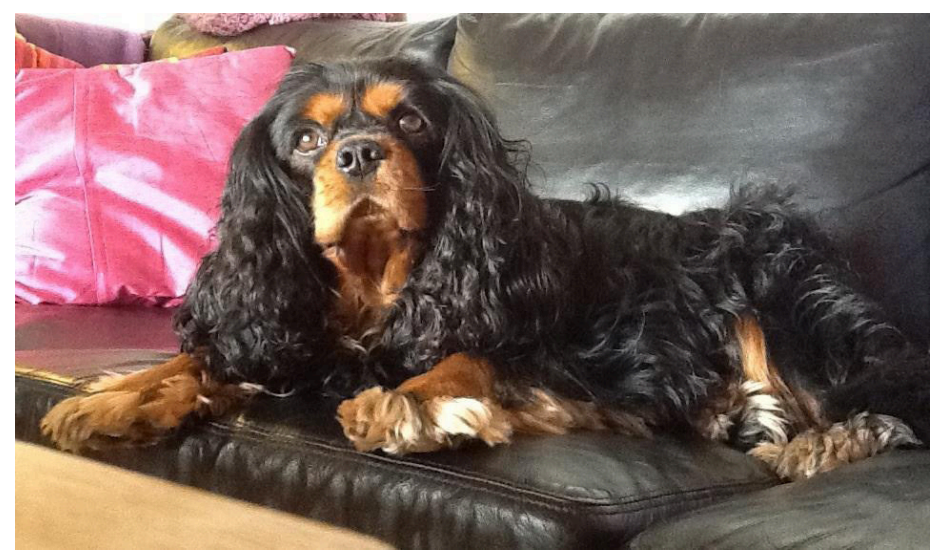

Hund med Facebookprofil? Coverbillede på Facebook. 2014. Privateje.

Det er en væsentlig pointe, at videnskaberne er nødt til at følge med tiden og forholde sig til, at Verden ikke er statisk. Historien blev også skrevet i går, og den blev ikke bare skrevet, den blev også fotograferet og lagt på nettet. Fotografiet er en naturlig del af det moderne menneskes dagligdag, og en af vore væsentligste historieskrivere. Ikke kun som episk fortælling om store, journalistisk fotogene begivenheder ude i Verden, men også som den lille fortælling om det almindelige menneske, den almene, digitale forbruger. Men hvordan forholder vi os så som historikere videnskabeligt til den visuelle, digitale eller 'postfotografiske' verden, vi befinder os i? Tør vi overhovedet begynde at arbejde med digitalt fotografisk kildemateriale, eller vil vi ikke røre det bedrageriske stof med en ildtang? Er vi for paralyserede af mediets muligheder til at tage det ved hornene? Bertelsen foreslår, at en ikke-lineær tilgang til fotografihistorien er vejen frem: "Det er ikke de teknologiske ændringer i sig selv, anskuet i et lineært teknologihistorisk perspektiv, der er interessante, men derimod det nye perspektiv, de sætter på historierne” (I5). 
Hans bog bygger på den tese, at et fotografi fra første halvdel af I8oo-tallet og et fra sidste halvdel af I9oo-tallet kan anskues ens, og for den sags skyld ud fra samme grundpræmisser som vi anskuer et maleri fra I70o-tallet. Det er lige præcis her, kunsthistorikerens og historikerens veje skilles. Historikerens vej er lineær, kronologisk og kontekstuel. Det betyder ikke, at den ikke brydes af forgreninger, sideveje og rundkørsler. Men dens pejlemærker ændrer ikke (så ofte) deres placering. Anden Verdenskrig putter sig ikke pludselig ned i I6oo-tallet. Historiens mange kontekster må forstås i forhold til hinanden kronologisk, og ophavsmænd til historiske kilder må både forstås i forhold til det samfund, de levede i, og det samfund, der lå før. Historiske kilder kan ikke løsrives fra deres historiske sammenhænge; de kan kun analyseres i forhold til dem. Også de kilder, der produceres i dag.

I den digitaliserede eller 'postfotografiske' medieverdens billedbombardement opstår der nogle helt konkrete verifikations-, fortolknings- og for den sags skyld bevaringsproblemer i digitaliseringsprocessen. Ifølge den historiske kildekritik er det alfa og omega at få besvaret kildernes hv-spørgsmål: Hvem har skrevet teksten, hvornår, hvor, hvordan, hvad handler den om og hvem optræder i den. Derefter formuleres de uddybende videnskabelige spørgsmål til den. Afhængigt af hvilken generation af det digitale fotografi, vi arbejder med, falder mange af disse oplysninger væk, hvis de da nogensinde har været der. Digitale billeder i cyberspace løsrives således ofte fra deres tilblivelseshistorik og bliver i en vis grad kontekstløse, proveniensløse. Det gør det svært at foretage en kildekritisk verifikationsproces, og uden verifikation er det svært at stille de rigtige spørgsmål til materialet. Hvis altså fotografierne anskues ud fra det første led i deres proveniens, tilblivelsen. Hvis vi derimod ser bort fra kildens manglende materialitet og betragter fotografiet som en del af den digitale kontekst, det indgår i på Internettet, kan vi måske stille hvspørgsmålene; ikke til billedet i kontekst af dets frembringelse, men til billedet i dets cyberkontekst. Grundlæggende er brugskonteksten for fotografier på Internettet blevet mindst lige så hv-interessant som konteksten for deres frembringelse i første led. Men er vi så pludselig ved at lave historikere om til medieanalytikere? Snarere er vi ved at udvide feltet for den historiske forskning - eller måske udviske de grænser, der implicit ligger i ordet "tvær" inden for "tværfaglighed", ved at samtænke vore egne metoder med de metoder, de øvrige humanistiske fagdiscipliner stiller til rådighed, uden at vi mister vore forskellige videnskabelige identiteter i processen.

\section{Konklusion}

Vores hverdag er fyldt med billeder. I dag kan vi knipse løs i en uendelighed - med en smartphone tager det under et minut at tage et billede og lægge det på Internettet. Der er intet teknisk besvær og ingen særlig økonomisk belastning forbundet med at kunne tage billeder. Ingen grund til at gøre sig umage - hvis den fotograferede havde lukkede øjne, tager vi bare et nyt, og et nyt, og et nyt. Det er blandt andet i den kontekst, fotografier opstår i dag. De er over hele den visuelle sendeflade, 
og det er nødvendigt, at også historikere forholder sig til, hvad vi kan bruge dem til i forskningssammenhæng. Det er muligt, at det inden for kunsthistorien giver mening at bryde med den lineære, kronologiske teknologihistorie, men vejen dertil har været lang og fyldt med mellemregninger. I forhold hertil er historiefaget lysår bagud - her er man først så småt begyndt at flirte med tanken om at billeder kan fungere som primære kilder og ikke blot som levn. At der på historiestudierne er en stigende interesse for visuelle studier er et skridt i den rigtige retning. Det er udtryk for en begyndende anerkendelse af de visuelle mediers betydning. Men de metodiske greb om de visuelle kilder er endnu i afprøvningsfasen, og der savnes en metodologi, som anerkender fotografiets potentiale og begrænsninger, men stadig forholder sig til det ud fra historiefagets metodik. Vi har fotohistoriens teknologikronologi i ryggen og de sidste mange årtiers visualitetsfilosofier at stå på skuldrene af. Vi behøver ikke at gentænke fotografiet; vi skal snarere gentænke historiefaget, så det bliver metodisk klædt på til at kunne rumme produkter af den moderne massekultur.

Fotografihistorie, forstået som den kronologiske opfattelse af mediets udvikling, har længe givet en række tidsbestemmende pejlemærker, der kunne hjælpe til at sætte fotografier ind i deres rette historiske kontekster. Men det er ikke længere nok at kunne genkende formater og teknikker og kunne sige: "Dette er et daguerreotypi, derfor er det sandsynligvis fra mellem I839 og I855, hvormed vi kan konstatere, at denne påklædning blev anvendt ved fotografering i den pågældende periode”; vi må kunne komme længere ind i fotografierne uden at begynde at fortolke ud fra præmisser, der måske gør sig gældende for kunstværker, men måske, måske ikke gør det for fotografier generelt. Spørgsmålet er stadig hvordan. Hvordan kan historikere arbejde med fotografi uden at forvandle sig til kunsthistorikere? Hvordan kan et fotografi inden for historieforskningen ændre status fra illustration til dokumentation? Hvordan kan et fotografi ændre historien? Udgangspunktet for at arbejde historisk med fotografi må være den traditionelle historiske kildekritik. Når først vi kan tolke fotografier ud fra de samme præmisser, som vi tolker tekster, er vi i gang. Vi kan godt låne begreber fra kunsthistorien - der er ingen grund til at opfinde den dybe tallerken igen. Men hvor den lineære, kronologiske behandling af et materiale $\mathrm{i}$ forhold til dets historiske kontekst ikke er altafgørende for den kunsthistoriske forskning, er den sine qua non for den historiske. De grundlæggende metodiske greb er således væsensforskellige inden for disse to grene af humaniora, og metoderne lader sig ikke umiddelbart overføre. Men derfor kan analysegenstandene godt være de samme. Kunsthistorien har ikke vundet hævd på fotografiet, blot fordi den har forholdt sig til det igennem længere tid. Det kan sagtens angribes med historiefagets kildekritiske metode - og det bør det. Med de digitale mediers udvikling og den visuelle cyber(lav)kulturs fotobombardement er det bydende nødvendigt, at det traditionelle historiefag begynder at forholde sig indgående til det fotografiske medie, også som led i den moderne individuelle kreative proces og fremstilling af selvet. Hvis tiden inden for historiefaget er moden på et brud, må det være et brud med forestillingen om, at det kun er kunsthistorien og de visuelle 
kulturstudier, der bør forholde sig til fotografier. Der er brug for en ny tilgang til de visuelle medier inden for historiefaget; ikke en adoption af kunsthistorien eller en ny fotografihistorie, men en ny visuel kulturhistorie, der forholder sig til visuel kultur ud fra historiefaglige metodediscipliner.

\section{LITTERATURLISTE}

Andersen, Hans Christian. H.C. Andersens Dagbøger X. 1873-1875. 30. juni 2006 <http://img.kb.dk/ ha/hcadag/hcadag_Io/gif/hcadagio_329.gif>.

Bertelsen, Lars Kiel. Fotografiets grå mytologi. København: Forlaget politisk revy, 2000.

Bertman, Sandra L. Facing Death: Images, Insights, and Interventions. London: Taylor \& Francis, I99I.

Berner, Marie-Louise. "En profession bliver til. Daguerreotypiets udbredelse I839-I86o". Dansk fotografihistorie. Red. Mette Sandbye. København: Gyldendal, 2004. I2-37.

Buciek, Keld. Fra problem til metode. En case-baseret indforing $i$ anvendelsen af kvalitative metoder til belysning af struktur-agent problematikken. Roskilde: Roskilde Universitetsforlag, 1996.

Burke, Peter. Eyewitnessing. The Uses of Images as Historical evidence. London: Reaktion Books Ltd, 200I. Eller, Povl. Historisk ikonografi. København: Dansk Historisk Fællesforening, 1964.

Fabritius, Elisabeth. P.S. Krøyers Hip, Hip, Hurra! Et kunstnergilde. København: Forlaget Vandkunsten, 2004 .

Frizot, Michel. "The daguerreotype, total impression of reality". A New History of Photography. Red. Michel Frizot. Köln: Könemann, 1998.

Kjeldstadli, Knut. Fortiden er ikke hvad den har varet. En indforing i historiefaget. Frederiksberg: Roskilde Universitetsforlag, 2002.

Langford, Michael. Fotografiens historie. Oversat og forarbejdet efter den engelske The Story of Photography (London: Focal Press, 1980) af Bjørn Ochsner og Knud Søgaard. København: Aschehoug, I98I.

Olden-Jørgensen, Sebastian. Til kilderne! Introduktion til historisk kildekritik. København: Gads Forlag, 200 .

Panofsky, Erwin. Meaning in the Visual Arts. Chicago: University of Chicago Press, 1955.

Poe, Edgar Allan. "The Daguerreotype“. I Alexander's Weekly Messenger, I5. januar I840, s. 2. <http:// www.yale.edu/amstud/inforev/poe.html>.

"Portrætter af HCA". H.C. Andersens dagbøger. Illustrationer. 5. September $2006<$ http://www.kb.dk/ elib/mss/hcadag/ill.htm>.

Ruby, Jay. Secure the Shadow. Death and Photography in America. Cambridge, Massachusetts \& London, England: The MIT Press, 1995.

Sontag, Susan. On Photography. London: Penguin Books, 1979.

Saabye, Marianne (red.). P.S. Krøyers fotografier. København: Den Hirschsprungske Samling, 1990. 